\title{
ENVIRONMENTAL MANAGEMENT ACCOUNTING. A CASE STUDY FOCUSING ON A ROMANIAN MOROCCO GOODS PRODUCER
}

\author{
Gabriel Jinga ${ }^{1}$ \\ Mădălina Dumitru ${ }^{2}$ \\ Gabriel Radu ${ }^{3}$ \\ Flavia Stoian ${ }^{4}$
}

\begin{abstract}
In this article our focus is to develop a case study concerning the environmental management accounting (EMA) applied in a Romanian company which is acting as a morocco goods (shoes, bags, belts, wallets and other leather accessories) producer. We use as a research methodology the case study due to the fact that it is most desriptive in assesing the specific settings that are of interest to the concerned users. We have selected this company because of its impact on the related environment. The study relies on the EMA framework designed by Burritt, Hahn and Schaltegger (2002). We have made a material life-cycle assessment for one type of product. Our study has multiple data sources (such as a large spectrum of related persons including production and financial managers, accountants, and company owners and CEO) as well as a variety of research methods (direct observation, documentation, archival records, and interviews). Our objective is to prove that EMA can help companies act in an integrated manner, improving their production process and their performance. By implementing EMA, managers can identify ways to improve the eco-efficiency of the companies.
\end{abstract}

Keywords: environmental management accounting, morocco goods, Romania, case study

JEL Code: Q56

\section{Introduction}

Environmental management accounting (EMA) is "the management of environmental and economic performance through the development and implementation of appropriate environmentrelated accounting systems and practices" (IFAC 1998: para 1).

The world changed in the $21^{\text {st }}$ century, as the global financial crisis, the increasing pressure on the resources, the global warming are realities of the days we live. Environmental issues increasingly influence the economic performance of companies and organizations (Burritt and Tingey-Holyoak, 2012). Growth in environmental regulations, rising cost of electricity, fuel, and raw materials, the demand for environmental information by investors, the sustainability issues required by the important partners along the supply chain, and requirements of business and private customers for environmentally benign products provide several important examples. Thus, managers need to incorporate environmental considerations into their regular decision-making activities and processes. The financial impact of environmentally-related decisions is often underestimated or not even considered at all (Burritt, Schaltegger, and Zvezdov, 2010). In addition,

\footnotetext{
${ }^{1}$ The Bucharest University of Economic Studies, Romania,e-mail: gabriel.jinga@gmail.com

${ }^{2}$ The Bucharest University of Economic Studies, Romania, e-mail: Madalina.Dumitru@cig.ase.ro

${ }^{3}$ The Bucharest University of Economic Studies, Romania, e-mail: gabriel.radu@cig.ase.ro

${ }^{4}$ The Bucharest University of Economic Studies, Romania, e-mail: Flavia.Stoian@gmail.com
} 
a company that is not paying attention to the environmental aspects of its production process, generating pollution and waste, is not efficient and this will have consequences on its overall performance (Schaltegger et al., 2008). The United Nations Environment Programme (UNEP Industry and Environment) calls for "the continuous application of an integrated preventive environmental strategy applied to processes, products and services to increase eco-efficiency and reduce risks to humans and the environment" (http://www.unepie.org/cp/home.html).

Accounting has long been presented as being used by management and external users (Schaltegger and Burritt, 2000; Lesourd and Schilizzi, 2001; Briciu et al., 2013). For sustainability accounting there is a need for costs and benefits of environmental and social matters to be identified, for measurement and quantification of these where appropriate, for provision of qualitative data when intangible costs and benefits arise, for the use of commonly accepted physical and monetary performance indicators, and for recognition that many impacts of companies take a long time to eventuate (Aras and Crowther, 2009).

At the moment, in Romania, there is a dualist accounting system and the accounting process is rather rules-based. Regarding the management accounting it is specified that "its organization depends on the enterprise" (Accounting Law 82/1991). Considering that ahead of this moment there was an integrated accounting system, in the moment of its change accountants understood that the organization of the management accounting (instead of the mode of the organization) depends on the company. This may be a reason for the management accounting to be in a shadow. At the same time, only companies acting in a few domains have to fulfil legal requirements regarding the environment. One characteristic of emerging economies and newly industrialized countries is that they lack good quantitative data related to the generation and use of environment-related information (Herzig et al., 2012). For instance, information in the major life cycle databases is characterized by an almost complete absence of life cycle inventories from emerging economy countries (e.g. Ecoinvent Centre, 2011).

This case study focuses on the application of EMA at Company A (anonymous here), a medium, family-run enterprise in Bucharest, the capital of Romania. The company produces morocco goods and deals with environmental issues such as odour, noise and waste. We rely on the EMA framework conceived by Burritt, Hahn, and Schaltegger (2002) by presenting the major (minor) applications of EMA at company A. We support the applications identified with an example of an input-output table prepared for one type of product manufactured by company A, the scrap computation (as waste is the biggest environmental issue in the case of this company) and the performance computed for the same product.

The remainder of this paper is organized as follows: a review of the relevant literature on EMA; the methodology description; the presentation of the research site and the results; conclusions, contributions and limitations of the study and future research avenues.

\section{Evidence on EMA - Literature review}

Management orientated path to sustainability accounting gives recognition of the importance of management decision making and views of corporate sustainability accounting as a set of tools that provides help to managers dealing with different decisions (Burritt and Schaltegger, 2010). For decision-making purposes, the focus is on developing accounting approaches to provide sustainability information, to design information processes and to understand empirically where in corporate practice the data comes from and the uses to which it can be put (Spence, Husillos and Correa-Ruiz, 2010).

The training of accountants to understand environmental issues and impacts as well as development of standardised guideline for measurement and reporting of environmental risks is needed (Medley, 1997; Durden, 2008). Nevertheless, authors are critical on the issue of 
environmental accounting education because of the reduced number of available courses and the lack of streaming (Gibson, 1997; Collison et al., 2000; Boyce, 2004). Further research and actual practice in the following areas are in need of more comprehension: environmental accounting education through the provision of a source of reference in an undersupplied market; the legitimacy and interest of practitioners being involved in environmental accounting issues; assurance of environmental information and the lack of standards; training of auditors of environmental information; the links between disclosure and policy making in relation to environmental information; and environmental accounting's role in continuous improvement (Medley, 1997; Burritt, 2012).

Unerman and O'Dwyer (2010) notice the reduced number of academic articles published between 1999 and 2008 addressing social, societal and/or ecological impacts of organisational activities, the professions, and how accounting can help provide information to mitigate negative externalities where costs of business activity are imposed on others. Previous literature on EMA development identifies two main directions. The first is focused on the economic efficiency and tries to identify the link between the economic performance and the environmental performance (King and Roberts, 2013; Klassen and McLaughlin, 1996; Bennett et al., 1999). The second is focused on the social theories and tries to identify the relationship between environmental activities and social structure and pressure (Schaltegger et al., 2008), most of the studies being directed to the legitimation of the companies in front of various groups of stakeholders. Bebbington and Gray (2001), Antheaume (2004), Herbohn (2005), Lamberton (2005), Bebbington, Brown and Frame (2006), Jones (2010) analyse existing models of sustainability accounting, propose and experiment with new models, and create frameworks for environmental reporting. Future research needs to address the real challenge to corporate management, for example to develop tools for sustainability accounting for specific business situations (Schaltegger and Burritt, 2010). Conducting theoretical research that is useful to corporate managers (Lawler et al., 1985), based on a pragmatic orientation (Pfeffer, 2008), is necessary if sustainability accounting is to demonstrate its fitness for purpose.

Regarding the accounting practices, there are a number of experimental models that meet the conditions of a full costing system. In Romania, such models have not yet been implemented, indicating an information void regarding the potential benefits of such models (Guse et al., 2011).

In Romania, the companies are required to declare to the Environment Fund Agency (Order 578/2006):

- Ferrous and nonferrous scrap;

- Emissions of pollutants into the air from stationary sources;

- Emissions of pollutants into the air from mobile sources;

- Using new lands for recyclable waste storage;

- Packaging introduced into the market (PET, aluminum, plastic, glass, metal, paper and wood introduced on the national market);

- Substances classified as being dangerous for the environment: medicines, cosmetics, food etc.

- Wood;

- New and/or used tires introduced into the market;

- Amount paid for the hunting funds management;

- Eco tax;

- Municipal and similar waste;

- Oils reused.

Romania is a country in which a law regarding the environment dated in the 60 s is still in force. There is no education for the environment's protection and in many communities nothing 
happens on this problem (for instance, there are communities around Bucharest that do not have differentiated waste collection, recycling programs etc.).

A specific tool used in EMA is the material flow cost accounting (MFCA). Monetary quantification of material losses is the overall objective of MFCA. MFCA treats waste as material loss and assigns to it a portion of raw material and processing cost (Strobel and Redmann, 2002; Kokubu et al., 2009). The approach aims to reduce waste-induced inefficiencies in business decision-making. The major difference from conventional cost accounting is that material and other costs of processes are first allocated to products and then also allocated to product-related waste based on physical activity-based drivers. MFCA implies a linear relationship between inputs and outputs: a reduction of product-related waste leads to a reduction of input flows (Schaltegger and Burritt, 2000; Wagner and Enzler, 2006; METI, 2007).

\section{The research methodology}

Our study has multiple data sources (large spectrum of contact persons including production and financial managers, accountants, and company owners/senior management) and a variety of research methods (direct observation, documentation, archival records, and interviews). We collected the data from the research site through direct observation, interviews, and internal or public documents. The lead author is working for the company as a financial manager, so he has directly noticed the management activities since July 2002. The author's employment in the organization proved to be very helpful, especially for the observation process. It offered the author considerable freedom of movement and almost no restrictions in asking questions and collaborating with the management. The lead author was able to attend a number of meetings, their subject including the budget of the company, departmental strategy, discussions related to the environmental impact, productivity etc. In 2012 he was asked by the management to be a part of a project attempting to find a solution to deal with the scrap leather resulted from the production process. The interviews were conducted with one of the owners, the financial manager and the production manager. Each interview lasted from 60 to 90 minutes. Written information was kept from the interviews and analysed by the research team afterwards.

This study is interventionist following Malmi and Granlund (2009): "[b]y acting as experts in real-life development projects, we can simultaneously produce research results that are both practically (practice relevant guaranteed) and theoretically interesting."

For this article we used the environmental management accounting framework developed by Burritt, Hahn and Schaltegger (2002). EMA decision settings and tools (based on Burritt, Hahn, and Schaltegger, 2002) can be summarized as follows:

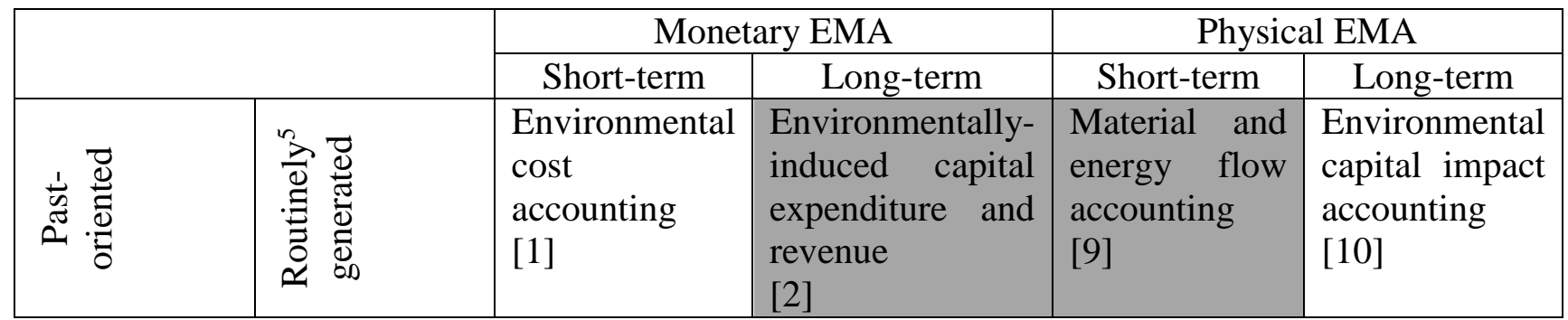

\footnotetext{
${ }^{5}$ Routineness of information: is the required information gathered regularly or does it have to be collected ad hoc, for this single instance only?
} 


\begin{tabular}{|c|c|c|c|c|c|}
\hline & $\frac{0}{\frac{8}{1}}$ & $\begin{array}{l}\text { Ex-post } \\
\text { assessment of } \\
\text { relevant } \\
\text { environmental } \\
\text { costing } \\
\text { decisions } \\
{[3]}\end{array}$ & $\begin{array}{l}\text { Ex-post } \\
\text { inventory } \\
\text { assessment of } \\
\text { projects } \\
\text { (including life } \\
\text { cycle costing - } \\
\text { LCC) } \\
\text { [4] }\end{array}$ & $\begin{array}{l}\text { Ex-post } \\
\text { assessment of } \\
\text { short-term } \\
\text { environmental } \\
\text { impacts } \\
\text { [11] }\end{array}$ & $\begin{array}{l}\text { Ex-post } \\
\text { inventory } \\
\text { appraisal of } \\
\text { physical } \\
\text { environmental } \\
\text { investments } \\
\text { (including life } \\
\text { cycle } \\
\text { assessment - } \\
\text { LCA) } \\
\text { [12] }\end{array}$ \\
\hline \multirow{2}{*}{ 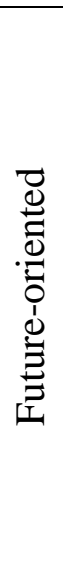 } & 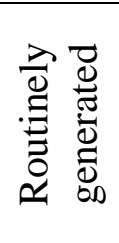 & $\begin{array}{l}\text { Monetary } \\
\text { environmental } \\
\text { budgeting } \\
{[5]}\end{array}$ & $\begin{array}{l}\text { Environmental } \\
\text { long-term } \\
\text { financial } \\
\text { planning } \\
\text { [6] }\end{array}$ & $\begin{array}{l}\text { Physical } \\
\text { environmental } \\
\text { budgeting } \\
{[13]}\end{array}$ & $\begin{array}{l}\text { Environmental } \\
\text { long-term } \\
\text { physical } \\
\text { planning } \\
{[14]}\end{array}$ \\
\hline & $\frac{8}{\frac{1}{1}}$ & $\begin{array}{l}\text { Relevant } \\
\text { environmental } \\
\text { costing } \\
\text { [7] }\end{array}$ & $\begin{array}{l}\text { Monetary } \\
\text { environmental } \\
\text { investment } \\
\text { appraisal } \\
\text { [8] }\end{array}$ & $\begin{array}{l}\text { Tools } \\
\text { designed to } \\
\text { predict } \\
\text { relevant } \\
\text { environmental } \\
\text { impacts } \\
{[15]}\end{array}$ & $\begin{array}{l}\text { Physical } \\
\text { environmental } \\
\text { investment } \\
\text { appraisal } \\
\text { [16] }\end{array}$ \\
\hline
\end{tabular}

Figure no. 1 - Application of the EMA framework (Burritt, Hahn, and Schaltegger, 2002) at company A

Note: Dark (light) grey boxes represent the major (minor) EMA applications

In our case company, we identified issues related to both monetary EMA (MEMA) and physical EMA (PEMA). MEMA "deals with environmental aspects of corporate activities expressed in monetary units and generates information for internal management use."

In order to measure and improve eco-efficiency it is not enough to measure the quantitative impact, it is also necessary to have the monetary information available and that the both types of data are consistent (Schaltegger and Burritt, 2000; Burritt, Hahn, and Schaltegger, 2002). Burritt, Hahn, and Schaltegger (2002) framework recognizes that decisions vary in terms of type of data (monetary or physical), time frame (short or long), scope (past or future) and periodicity (regular or ad hoc). Yet, the framework doesn't present the qualitative aspects of the information.

\section{Presentation of the company}

The research site of this article is Company A, a 100\% family-owned business (husbandwife). The company was established in 1992, the owners starting with 700 dollars in the retail domain with haute-couture fabrics. In the year 1996 they became the biggest fabrics reseller in the country (representing in Romania the leading European producer) and got in touch with the fashion world. In the beginning, they were importing shoes and other leather products from Italy.

In 2000, company A shifted from the fabrics trade to the production of shoes and other leather objects. The first shoe factory (of almost 600 square meters) was built with almost 200,000 EUR, where they produced manually at the beginning because of the lack of equipment. In the year 2002 the company exited almost entirely from the fabrics business and it opened a second factory 
(of 1,500 square meters). In the same year it closed the first factory. In 2004 the company invested in equipment, such as computerized cutting machines and production lines.

In 2007 a new factory was opened in a Romanian town with a tradition in the leather industry. The factory produced at the beginning 450 articles a day, but the production grew progressively. The consolidation of the company's position on Bucharest's market followed, by opening new shops in big commercial centres, but also by expansion to other cities in Romania.

For company A, 2008 was the year when the managers started making changes in the decision-making process. In 2008-2009 the company had to close a few stores. In 2008 it stopped the development on the Romanian market, and it started to open and franchise the business abroad. The company opened stores in Tel Aviv, New York, Paris etc., and it prepared a development plan for Europe, wishing to open stores in London, Greece, Russia, Poland, Ukraine or Vienna, according to one of the owners. In 2011, the company also started developing a platform for online selling.

In 2012 they doubled the production capacity of the factory established outside of Bucharest. The company is not listed at the stock exchange. This is a Romanian brand; however, one of the biggest disappointments of the owners is that there are no connected industries in Romania and everything is imported (raw materials, packaging materials etc.). The company is not ISO certified.

Today it is one of the first three companies in its domain in Romania. Briefly, the performance for 2012 can be presented as follows:

Company A's performance for 2012

\begin{tabular}{|l|r|}
\hline \multicolumn{1}{|c|}{ Items } & \multicolumn{1}{c|}{ Amounts } \\
\hline Financial aspects of performance & \\
\hline Sales (in RON) & $38,750,329.83$ \\
\hline Cost of sales (in RON) & $13,001,284.74$ \\
\hline Gross income (in RON) & $4,327,895.83$ \\
\hline Net income (in RON) & $3,599,124.83$ \\
\hline Return on assets (ROA) & $6.53 \%$ \\
\hline Return on investment (ROI) & $12.39 \%$ \\
\hline Return on sales (ROS) & $11 \%$ \\
\hline Operating income to sales ratio (OIS) & $10 \%$ \\
\hline Cost of goods sold to sales ratio (CGSS) & $34 \%$ \\
\hline Employees productivity & 364 \\
\hline Number of full-time employees & \\
\hline Number of employees divided by sales (ES) & 0.000009 \\
\hline Customers satisfaction & $95 \%$ \\
\hline
\end{tabular}

Source: compilation of the authors

The company has a general manager, a financial manager and an artistic manager. The Administrative Department has sixteen employees, of which: two human resources specialists, three accountants, three drivers. The Commercial Department has fifteen shops and a logistics centre. Each shop has a manager and four shop-assistants. The logistics centre has eleven commercial workers and a manager. The Production Department is split into two divisions: morocco goods and 
shoes. The morocco goods division has eighty-four employees, of which one manager, four administrative employees and seventy-nine workers. The shoes division has two hundred and one employees, of which two managers, six administrative employees and one hundred and ninety-four workers.

\section{EMA at company A}

Company A's organization of management accounting

In Romania most of the companies prepare only financial accounting information for reporting purposes. This was also the case of company A until 2007, when the company implemented an ERP system. The decision-making process changed ever since. Environmentrelated information is present in the form of reporting for the state authorities. This includes an annual report regarding the waste management and an annual report regarding the packaging materials and packaging waste. The owners of the company want to find a set of practical measures to improve their eco-efficiency in the future.

The production process consists only of manufacturing the shoes, bags and accessories. All the materials needed are purchased already prepared to be used in the production. The accounting process in company $\mathrm{A}$ is well organized thanks to the ERP system. The company is using the traditional cost computation method. The production cost is computed by adding a percentage of labour expenses and other overheads (for instance, rents, utilities) to the direct cost, in order to establish the selling price. This cost is computed at the beginning of the collection, twice a year. The standard cost is established as a percentage (30\%) of the selling price. The variances are computed as to the actual cost only at a global level. The financial manager says: "In this industry, everything depends on the collection, not on the cost. It's the collection that matters."

According to the financial manager, the most used ratio for the analysis of the profitability is EBITDA. This is computed per total or per cost centres. The cost centres the company is split in are: shoes, bags, administrative department, car park, distribution, the last one being also split into: shops, deposit, logistics.

"Till now the expenses were not separated into fix and variable, but the management wishes to implement this in order to be able to make scenarios. There was an idea to allocate the labour, using software, directly to the products. After cost-benefit analysis the management concluded that the practical constraints would be too large." (financial manager).

In the opinion of the financial manager, "a problem of the present system is the inventories level. There are inventories poorly purchased or finished goods produced without a marketing forecast and without knowing if a model will be sold in 100 or 500 pieces. The purchases are not efficient." To overcome this, the financial manager says that they want to improve the production planning, starting with the marketing prospects on a focus group type, knowing the quantity estimated to be sold for each collection. For the raw materials, the company wants to negotiate with the supplier the inventories to be returned, in order to pay only for the quantity used in fact. Thus, the credit control function would improve.

\section{Company A's motivation for using EMA}

Several reasons were previously stated in the literature regarding the decision of the management to use EMA (Burritt, 2005; Gray and Bebbington, 2001; Burritt and Schaltegger, 2001; O'Donovan, 2002): regulation imposing to demonstrate compliance, voluntary use as part of the responsibility accounting process, the quest for legitimacy, the will to reduce costs and obtain other benefits from using EMA (e.g. eco-efficiency improvement) etc. The company wants to implement EMA in order to improve its performance and to improve its production processes. 
Company A's most harmful impact on the environment refers to the disposal of the scrap leather. The impact is twofold: first, because of the amount, and second because of the type of scrap. The waste resulted from the cut of the shoes faces represent 50 to $70 \%$ of the total solid waste produced by the shoes factories, while for the natural leather the waste percentage is 25 to $35 \%$ and for the textile materials it is 20 to $25 \%$ (Albu, 2010). The materials used in the production process include leather, textiles, metallic accessories, wrapping materials and other consumables. It consumes electricity (generated by fossil fuels), and it generates waste (most of it made up of pieces of leather; the waste implies land use), dust and odour in the production facility. It also generates some greenhouse gas emissions because of the company's cars. Some of the adhesives are dangerous for the health of the employees. The dust resulted from the production process is stored in bags. The production process of company A has environmental impacts on the water, air and soil. For a general overview of the production process, we created an accounting system for material and energy flows and associated costs. As a starting point, a list of the most relevant production processes was made up.

The company introduced a separation of the types of waste in 2008 .

The company pays for the removal of the leather scrap approximately 10,000 lei per year.

\section{Production processes}

The steps in the production process refer to:

- Reception of raw materials;

- Cutting of flexible materials parts (parts for faces, exterior lining, intermediate linings);

- Stamping and preparing pieces of rigid materials;

- Preparation of the shoe upper assembly parts (faces): equalization, thinning, burning edges, painting edges, stamping, marking pieces ready for gluing etc.;

- Assembly by gluing and sewing uppers;

- Preparing the faces for drawing;

- Drawing the block;

- Completion and final inspection of footwear;

- Marking, packaging, storage and shipment of footwear.

Important environmental issues - data analysis

Input-output tables were prepared to track raw materials, packing materials, accessories, and other materials consumption. We present as an example the input-output table for one type of bag.

Input-output table for one type of product in November 2012

\begin{tabular}{|c|l|c|c|c|c|c|c|c|c|}
\hline \multicolumn{3}{|c|}{ Input } & \multicolumn{6}{c|}{ Output } \\
\hline Item & Amount & Unit & $\begin{array}{c}\text { Total } \\
\text { cost } \\
\text { (EUR) }\end{array}$ & $\begin{array}{c}\text { Data } \\
\text { quality } \\
\text { and } \\
\text { source }\end{array}$ & Item & Amount & Unit & $\begin{array}{c}\text { Total } \\
\text { cost } \\
\text { (EUR) }\end{array}$ & $\begin{array}{c}\text { Data } \\
\text { quality } \\
\text { and } \\
\text { source }\end{array}$ \\
\hline Leather & 61.46 & $\mathrm{~m}^{2}$ & $1,444.31$ & Calculated & $\begin{array}{l}\text { GRET } \\
\text { A XL } \\
\text { bag }\end{array}$ & 30 & pieces & $1,788.19$ & Calculated \\
\hline
\end{tabular}




\begin{tabular}{|l|l|l|l|l|l|l|l|l|l|}
\hline $\begin{array}{l}\text { Metallic } \\
\text { accessories }\end{array}$ & 1,726 & pieces & 13.88 & Calculated & $\begin{array}{l}\text { Scrap } \\
\text { leather }\end{array}$ & 1.2025 & $\mathrm{~m}^{2}$ & 28.26 & Calculated \\
\hline $\begin{array}{l}\text { Other } \\
\text { materials }\end{array}$ & 56.98 & EUR & 56.98 & Calculated & Dust & 0.1 & $\mathrm{~m}^{3}$ & - & Estimated \\
\hline Electricity & 10 & $\mathrm{kWh}$ & 1.28 & Estimated & & & & & \\
\hline Labour & 300 & EUR & 300 & Estimated & & & & & \\
\hline
\end{tabular}

Source: compilation of the authors

Important environmental issues refer to:

Table no. 3

Materials used and scrap estimated to be generated by the production process for the production of 32,750 pairs of shoes and 20,160 other morocco goods

\begin{tabular}{|c|c|c|c|c|c|}
\hline No & Materials & Quantity/year & $\begin{array}{c}\text { Packaging } \\
\text { material }\end{array}$ & $\begin{array}{c}\text { Waste } \\
\text { quantity }\end{array}$ & Waste management \\
\hline & Raw materials & & & & \\
\hline 1 & $\begin{array}{l}\text { Natural } \\
\text { leather }\end{array}$ & $11,400 \mathrm{~kg}$ & \multirow[t]{3}{*}{ Plastic } & $\begin{array}{l}1,620 \mathrm{~kg} \\
(14.21 \%)\end{array}$ & Specialised company \\
\hline 2 & $\begin{array}{l}\text { Synthetic } \\
\text { leather }\end{array}$ & $1,600 \mathrm{~kg}$ & & $\begin{array}{l}37 \mathrm{~kg} \\
(2.31 \%)\end{array}$ & Specialised company \\
\hline 3 & $\begin{array}{l}\text { Textile } \\
\text { materials }\end{array}$ & $3,600 \mathrm{~kg}$ & & $\begin{array}{l}85 \mathrm{~kg} \\
(2.36 \%)\end{array}$ & Specialised company \\
\hline 4 & Moltopren & $350 \mathrm{~kg}$ & \multirow{4}{*}{$\begin{array}{l}\text { Metallic } \\
\text { bottles }\end{array}$} & \multirow{4}{*}{$\begin{array}{l}150 \text { metallic } \\
\text { boxes }\end{array}$} & \multirow[t]{4}{*}{ Used within the company } \\
\hline 5 & Adhesives & $900 \mathrm{~kg}$ & & & \\
\hline 6 & $\begin{array}{l}\text { Water-based } \\
\text { paints }\end{array}$ & $300 \mathrm{~kg}$ & & & \\
\hline 7 & Thinners & 201 & & & \\
\hline 8 & Cardboard & $1,200 \mathrm{~kg}$ & Bulk & & \\
\hline 9 & Inner soles & 32,750 pairs & \multirow{10}{*}{$\begin{array}{l}\text { Cardboard } \\
\text { boxes }\end{array}$} & \multirow{10}{*}{$\begin{array}{l}1,000 \\
\text { kg/year }\end{array}$} & \multirow{10}{*}{$\begin{array}{l}\text { Temporarily stored and } \\
\text { delivered to a specialised } \\
\text { company }\end{array}$} \\
\hline 10 & Toes & 9,600 pieces & & & \\
\hline 11 & Soles & 32,750 pairs & & & \\
\hline \multirow[t]{2}{*}{12} & $\begin{array}{l}\text { Other } \\
\text { stiffeners }\end{array}$ & 9,600 pieces & & & \\
\hline & Materials & & & & \\
\hline 13 & $\begin{array}{l}\text { Metal } \\
\text { accessories }\end{array}$ & $7,300 \mathrm{~kg}$ & & & \\
\hline 14 & $\begin{array}{l}\text { Sewing } \\
\text { thread }\end{array}$ & $2,000 \mathrm{~m}$ & & & \\
\hline 15 & $\begin{array}{l}\text { Sewing } \\
\text { needles }\end{array}$ & 9,600 pieces & & & \\
\hline 16 & $\begin{array}{l}\text { Marking } \\
\text { pencils }\end{array}$ & 18,000 pieces & & & \\
\hline \multirow[t]{2}{*}{17} & Tape sealed & 200,000 pieces & & & \\
\hline & $\begin{array}{l}\text { Wrapping } \\
\text { materials }\end{array}$ & & & & \\
\hline 18 & Paper & $2,820 \mathrm{~kg}$ & - & $400 \mathrm{~kg}$ & Temporarily stored and \\
\hline
\end{tabular}




\begin{tabular}{|l|l|l|l|l|l|}
\hline & & & & & $\begin{array}{l}\text { delivered to a specialised } \\
\text { company }\end{array}$ \\
\hline 19 & $\begin{array}{l}\text { Cardboard } \\
\text { boxes }\end{array}$ & 32,750 pieces & - & - & \\
\hline 20 & Plastic bags & $140 \mathrm{~kg}$ & - & - & \\
\hline 21 & Tying rope & $450 \mathrm{~kg}$ & - & - & \\
\hline
\end{tabular}

Source: compilation of the authors

\section{Interpretation of data}

Input-output tables help company A to trace environmental costs. Using them, it is possible to estimate the financial consequences of material losses in production. An example of the tracing of environmental costs is given in table 4.

Profit computation (in EUR)

\begin{tabular}{|l|r|}
\hline \multicolumn{1}{|c|}{ Items } & GRETA XL bag \\
\hline Sales & $19,320.00$ \\
\hline Direct production costs & $1,816.45$ \\
\hline Electricity & 1.28 \\
\hline Wasted raw materials & 28.26 \\
\hline Raw materials in product & $1,429.93$ \\
\hline Other materials & 56.98 \\
\hline Labour & 300 \\
\hline Operating profit & $17,503.55$ \\
\hline
\end{tabular}

Source: compilation of the authors

Electricity accounts only for $1 \%$ of the direct production costs. Wasted raw materials are more important, being about $2 \%$ of the quantity used and about $1.55 \%$ of the amount. It is impossible to avoid this waste completely. However, measures were and will be taken in order to reduce the amount of waste and manage its treatment.

\section{Measures to increase eco-efficiency}

The implementation of the material flow cost accounting allows the company to identify the waste processing costs and processes with large raw material losses.

As we mentioned before, the most harmful impact of the company on the environment refers to the use and disposal of the leather. In order to limit the impact, the company started recently replacing the leather with textiles for the production process for some articles (such as some models of bags). In 2008 the company hired specialized companies for dealing with scrap leather before throwing them. In 2012 it signed a contract to investment in equipment designed to reduce the loss of leather (through computerized cut). At present, the company is involved in a research project which aims to create the possibility for the scrap leather to be used as a raw material for cement.

Another problem that the company has to deal with because of the production process is the dust and odour resulted. These can have an impact on the health of the employees. In order to prevent it, the company purchased in 2012 a new ventilation system. This improved the working conditions and increased productivity. The number of headaches and other illnesses decreased.

The electricity used in the production process does not have an important value compared with the rest of the production costs. Yet, the company is also using electricity in the administrative department and more than twelve shops only in Romania. Regarding this aspect, the company is 
using a system for electricity consumption control and eco bulbs in the administrative department. They have a system for turning off the central heating during the night, but for the water they use normal tabs. The buildings have insulation and the windows are double glazed.

\section{Conclusions}

After 2007 a group of managers worked to improve the company's decision making process. One of the paths followed was to include the environmental issues in the decision-making process. Some of their actions involved the environmental impacts of the company. Thus, some measures were taken in this regard (for instance, the differentiated collection of waste, hiring a company to remove the scrap leather paid with about 2,000 EUR/year etc.). Usually, this happened without a systematic linkage to monetary figures and performance outcomes.

For Company A, the decision of using EMA was generated by its will to increase the efficiency of its processes. Thus, the company could reduce costs and waste. In this case study we presented both the physical and monetary flows. The use of MFCA highlighted the importance of avoiding material losses and provided incentives for measures of efficiency improvement. This is an example of a win-win situation.

One of the limits of the research generates from the use of a single case study. It is acknowledged that case studies offer low possibilities for repetition and generalizability (Yin, 1994). Yet, in the areas in which there are few previous studies, they can provide interesting explanations and descriptions (Burritt and Saka, 2006).

A further analysis for this company refers to the decision of putting in practice the research project aiming to transform the scrap leather into cement. If new products are developed (such as the cement using the scrap leather), regulatory bodies should focus on developing markets for them.

The EMA information obtained in the company A is limited in the present, an accounting inertia (Oldroyd, 1999) being noticed. This happens not only because of the company's management, but also because of the regulations in force.

In our study, we presented company A's environmental impacts during the production process. However, in other cases a life cycle analysis can be made, as the products have impacts on the environment during their entire life. For instance, transportation is necessary during all the cycles (the most important being the transportation of the raw materials, which are all imported). From the environmental point of view, transportation is associated with the depletion of the natural resources (as fossil fuels are mostly used) and with the global warming. Yet, in our example we did not take into account the transportation as it is outsourced.

The MCFA proved most of the company A's assumptions: that the most important impact is the waste, thus the company has to reduce the scrap resulting in the production process maintaining the quality in the same time, and that the consumption of energy should be minimized. This is an important finding from the decision-making point of view, as the managers know on which process to act for further improvements. Our study proves that applying EMA can improve the performance of the company, without involving a big conceptual or human effort.

\section{Acknowledgement}

This paper was co-financed from the European Social Fund, through the Sectorial Operational Programme Human Resources Development 2007-2013, project number POSDRU/159/1.5/S/138907 "Excellence in scientific interdisciplinary research, doctoral and postdoctoral, in the economic, social and medical fields -EXCELIS", coordinator The Bucharest University of Economic Studies 


\section{References}

1. Albu L., 2010. Cartea albă a industriei de pielărie, încălţăminte şi marochinărie din România, Bucureşti, Editura CERTEX

2. Antheaume N., 2004. Valuing External Costs - From Theory to Practice: Implications for Full Cost Environmental Accounting, European Accounting Review, 13.3, pp. 443 - 464

3. Aras G., Crowther D., 2009. Corporate sustainability reporting: a study in disingenuity?, Journal of Business Ethics Supplement, Vol. 87, pp. 279-288

4. Bebbington J., Brown J., Frame B., 2006. Accounting technologies and sustainability assessment models, Ecological Economics, 61, pp. $224-236$

5. Bebbington J., Gray R., 2001. An account for sustainability: failure, success and a reconceptualization, Critical Perspectives on Accounting, 12 (5), pp. 557 - 588

6. Boyce G., 2004. Critical accounting education: teaching and learning outside the circle, Critical Perspectives on Accounting, Vol. 15, No. 4/5, pp. 565-86

7. Briciu S., Topor D. I., Căpuşneanu S., 2013. Integrated methods for performance measurement in entities from the wine sector in Romania, Annales Universitatis Apulensis Series Oeconomica, nr. 15/2013, vol. 2, pp. $367-383$

8. Burritt R. L., Schaltegger S., 2001. Eco-efficiency in corporate budgeting, Environmental Management and Health, 12 (2 \& 3), pp. 158e74

9. Burritt R. L., 2005. Challenges for environmental management accounting, In: Pall Rikhardsson, Martin Bennett, Stefan Schaltegger, Jan Jaap Bouma, editors, Implementing environmental management accounting: status and challenges, Kluwer Academic Publishers, Boston/Dordrecht/London

10. Burritt R. L., 2012. Environmental performance accountability: planet, people, profits, Accounting, Auditing and Accountability Journal, vol. 25, no. 2, 2012, pp. 370-405

11. Burritt R. L., Hahn T., Schaltegger S., 2002. Towards a comprehensive framework for environmental management accounting: links between business actors and environmental management accounting tools, Australian Accounting Review, 12, pp. 39-50

12. Burritt R. L., Saka C., 2006. Environmental management accounting applications and ecoefficiency: case studies from Japan, Journal of Cleaner Production, 14, pp. $1262-1275$

13. Burritt R. L., Schaltegger S., 2010. Sustainability accounting and reporting: fad or trend?, Accounting, Auditing and Accountability Journal, vol. 23, no. 7, pp. 829-846

14. Burritt R. L., Schaltegger S., Zvezdov, 2010. Carbon management accounting: practice in leading German companies, Centre for Accounting, Governance and Sustainability Occasional Working Papers, No. 2, May, University of South Australia, Adelaide

15. Burritt R. L., Tingey-Holyoak J., 2012. Forging cleaner production: the importance of academic-practitioner links for successful sustainability embedded carbon accounting, Journal of Cleaner Production, 36, pp. 39-47

16. Collison D. J., Gray R. H., Owen D. L., Sinclair D., Stevenson L., 2000. Social and environmental accounting and student choice: an exploratory research note, Accounting Forum, Vol. 24, No. 2, pp. 170-86

17. Durden C., 2008. Towards a socially responsible management control system, Accounting, Auditing \& Accountability Journal, Vol. 21, No. 5, pp. 671-94

18. Gibson K., 1997. Notes: Courses on environmental accounting, Accounting, Auditing and Accountability Journal, Vol. 23, No. 7, pp. 584-93

19. Gray R. H., Bebbington J., 2001. Accounting for the environment. 2nd ed., London: Sage Publications 
20. Gușe G. R., Dascălu C., Caraiani C., Lungu C. I., 2011. New Approaches to Costing Models in Romania: The Recognition of Externalities, Annals. Economic Science Series, Timisoara, XVII, pp. 934-942

21. Herbohn K., 2005. A full cost environmental accounting experiment, Accounting, Organizations ans Society, 30, pp. $519-536$

22. Herzig C., Viere T., Schaltegger S., Burritt R. L., 2012. Environmental Management Accounting. Case studies of South-East Asian Companies, Routledge

23. IFAC, 1998. Environmental management in organizations: the role of management accounting [Study \#6], New York: Financial and Management Accounting Committee

24. Jones M. J., 2010. Accounting for the environment: Towards a theoretical perspective for environmental accounting and reporting, Accounting Forum, 34, pp. 123 - 138

25. King M., Roberts L., 2013. Integrate. Doing Business in the $21^{\text {st }}$ Century, Cape Town: Juta

26. Kokubu K., Campos M. K. S, Furukawa Y., Tachikawa H., 2009. Material flow cost accounting with ISO 14051, ISO Management Systems (January-February), pp. 15-18

27. Lamberton G., 2005. Sustainability accounting - a brief history and conceptual framework, Accounting Forum, 29, pp. 7 - 26

28. Lawler E. E., Mohrman A. M., Mohrman S. A., Ledford G. E., Cummings T. G., Associates, 1985. Doing research that is useful for theory and practice, San Francisco: Jossey-Bass

29. Lesourd J-B., Schilizzi S., 2001. The Environment in Corporate Management, New Directions and Economic Insights, Edward Elgar, Cheltenham

30. Malmi T., Granlund M., 2009. In search of management accounting theory, European Accountin Review, 18, pp. 597-620

31. Medley P., 1997. Notes: Environmental accounting: what does it mean to professional accountants?, Accounting, Auditing \& Accountability Journal, Vol. 23, No. 7, pp. 594-600

32. METI (Japanese Ministry of Economy, Trade, and Industry), 2007. Guide for material flow cost accounting, Tokyo: METI

33. O'Donovan G., 2002. Environmental disclosures in the annual report: extending the applicability and predictive power of legitimacy theory. Accounting, Auditing and Accountability Journal, 15 (3), pp. 344e71

34. Oldroyd D., 1999. Historiography, causality and positioning: An unsystematic view of accounting history, Accounting Historian Journal, 26 (1), pp. 83-102

35. Pfeffer J., 2008. What ever happened to pragmatism?, Journal of Management Inquiry, 17 (1), pp. 57-60

36. Schaltegger S., Bennett M., Burritt R. L., Jasch C., 2008. Environmental management accounting for cleaner production, Dordrecht: Springer

37. Schaltegger S., Burritt R. L., 2000. Contemporary environmental accounting: issues, concepts and practice, Sheffield: Greenleaf

38. Schaltegger S., Burritt R. L., 2010. Sustainability accounting for companies: Catchphrase or decision support for business leaders?, Journal of World Business, 45, pp. 375-384

39. Spence C., Husillos J., Correa-Ruiz C., 2010. Cargo cult science and the death of politics: a critical review of social and environmental accounting research, Critical Perspectives on Accounting, Vol. 21, No. 1, pp. 76-89

40. Strobel M., Redmann C., 2002. Flow cost accounting, an accounting based approach on the actual flows of materials, in Bennett, M., Bouma, J.J, and Wolters, T. (eds) Environmental management accounting: informational and institutional developments, Dordrecht: Kluwer, pp. 67-82 
41. Unerman J., O'Dwyer, B., 2010. The Relevance and Utility of Leading Accounting Research, Research Report 120, Certified Accountants Educational Trust, Association of Chartered Certified Accountants, London

42. Wagner B., Enzler S. (eds), 2006. Material flow management: improving cost efficiency and environmental performance, Heidelberg: Physica

43. Yin R., 1994. Case study research: design and methods. 2nd ed., Beverly Hills, CA: Sage Publishing 